\title{
Use of extractable lipofuscin for age determination of blue crab Callinectes sapidus
}

\author{
Se-Jong Ju, David H. Secor, H. Rodger Harvey* \\ Chesapeake Biological Laboratory, University of Maryland Center for Environmental Science, PO Box 38, Solomons, \\ Maryland 20688, USA
}

\begin{abstract}
The blue crab Callinectes sapidus is an economically and ecologically important species in many temperate estuaries, yet stock assessments have been limited to length-based methods for demographic analyses. We evaluated the potential of age pigments (lipofuscins) sequestered in neural tissue of eye-stalks and brains to estimate the age of blue crabs collected from Chesapeake Bay and Chincoteague Bay. The rate of lipofuscin accumulation was determined using crabs of known age reared in the laboratory. Age pigments were extracted from neural tissues (eye-stalk or brain), quantified, and normalized to protein content to allow comparisons across tissue types and crab sizes. Fieldcollected blue crabs ( 35 to $185 \mathrm{~mm}$ carapace width) contained highly variable levels of age pigments (coefficient of variation $=58 \%$ ). Lipofuscin level was significantly related to carapace width, but not significantly different between gender or sampling location. In juveniles (40 to $70 \mathrm{~mm}$ carapace width) reared for $6 \mathrm{mo}$, the age pigments showed no significant change during the rapid summer growth period, but significantly increased dunng fall (after $3 \mathrm{mo}$ ). Lipofuscin contents in known-age reared crabs were positively related to chronological age. Modal analysis of lipofuscin for field-collected adult males provided separation of multiple modes, whereas carapace width showed only a single broad mode. These results confirm the potential use of lipofuscin for age estimation of blue crabs.
\end{abstract}

KEY WORDS: Blue crab - Callinectes sapidus - Lipofuscin - Age pigment - Eye-stalk - Brain - Chesapeake Bay Stock assessment

\section{INTRODUCTION}

Knowing the age structure of wild populations is fundamental for effective fisheries management. For the many species of fishes, age can be determined with reasonable certainty using hard parts which produce a characteristic growth increment over time, e.g. otoliths, scales, or spines (Hjort \& Lea 1914, Secor et al. 1995). Age determination of crustaceans, however, is difficult because they lack permanent hard structures. Crustaceans periodically molt their calcareous exoskeleton as they grow, removing all external evidence of age or previous size. At each molt extra space is created which is filled over time by the growth of soft tissue. As a result, crustacean soft tissue growth may be continuous while carapace size, the most frequently used measure of growth and age, is a discontinuous

\footnotetext{
- Addressee for correspondence.

E-mail: harvey@cbl.umces.edu
}

function over time. For crustaceans such as the commercially important blue crab Callinectes sapidus modal analysis of length frequency data is often used because methods for direct ageing do not exist (e.g. Rothschild et al. 1992). Unfortunately, length-based methods are inherently imprecise, particularly when the spawning season is protracted as in the blue crab. This can cause a wide distribution of sizes in a single year class (Prager et al. 1990). Due to discontinuous growth patterns, protracted spawning season, and variability in molting frequency, it has been difficult to accurately determine chronological age of crustaceans captured in the field using modal analysis.

The critical need for age structure data on crustacean populations has led to alternative methods for age determination. Among the most successful utilize are biochemical or histological approaches that measure condensation products which accumulate in postmitotic tissue (i.e. neural) as a consequence of peroxidation reactions. First observed in humans by 
Hannover (1842), these fluorescent age pigments (FAP), termed lipofuscins (LF), are now recognized as one of the most clearly discernable markers of ageing in cells (see review by Gutteridge 1987). The accumulation of FAP or LF has been applied as an alternative to conventional morphometric age determination techniques in crustaceans including lobster (Belchier et al. 1994. Sheehy et al. 1996, Wahle et al. 1996), crayfish (Sheehy 1992, Belchier et al. 1998), prawn (Sheehy et al. 1995), and krill (Ettershank \& George 1984, Nicol et al. 1991). Estimating LF content of animal tissues rely on 1 of 2 approaches. The first involves analysis of histological sections by counting and quantifying pigment containing granules using fluorescence microscopy (O'Donovan \& Tully 1996, Sheehy et al. 1996, Wahle et al. 1996, Belchier et al. 1998). The second method relies on extraction of the hydrophobic products using organic solvents, with subsequent measurement of fluorescence by spectrophotometric analysis (Davis et al. 1982, Hirch \& Anger 1987, Nicol et al. 1991).

We evaluated the potential for extractable LF to provide an accurate age determination of blue crabs. Methodology for measurement of extractable LF was first evaluated and refined. The relationship between chronological age and LF level was then tested using known-age juveniles. Temperature and salinity effects on LF accumulation rate were also tested for laboratory-reared, and field-collected crabs, respectively, because there is evidence that LF accumulation may be directly correlated with metabolic rate (Katz et al. 1984, Clarke et al. 1990, O'Donovan \& Tully 1996). Finally, modal analyses of both LF- and carapace width (CW)-based 'indices' of age were compared using field-caught specimens.

\section{MATERIALS AND METHODS}

Sampling and laboratory rearing. Blue crabs were collected in the fall of 1996 and the summer of 1997 near Calvert Cliffs, Maryland, USA. Most crabs were immediately sacrificed and analyzed. One subset of crabs was retained for rearing experiments to determine the minimum time period (month, year) that changes in LF concentration could be resolved under known environmental conditions. A group of juvenile crabs representing spring or summer cohort of 1996 (40 to $70 \mathrm{~mm} \mathrm{CW}$ ) were reared for a 6 mo period. Crabs were held in individual cages (size: $20 \times 40 \times 15 \mathrm{~cm}_{\text {i }}$ total volume: 3.6 l) under constant flowing seawater $\left(200 \mathrm{ml} \mathrm{min}^{-1}\right)$ at a constant $\left(20^{\circ} \mathrm{C}\right)$ or ambient (20 to $28^{\circ} \mathrm{C}$, mean $=24^{\circ} \mathrm{C}$ ) temperatures. They were fed small pieces of fish (typically menhaden Brevoortia tyrannus) every other day. Salinity during the period ranged from 10 to $15 \%$. Size as CW (including lateral spines) for all crabs was measured monthly, and subgroups (n $=3$ to 10 ) were periodically sacrificed for LF extraction and measurement. In addition, 3 groups of juvenile blue crabs ( $\mathrm{n}=9$ ) of known age $(7.6,8$, and 12 mo old) originally collected as megalope from lower estuaries of the Chesapeake Bay during the summer and fall of 1996 and reared under known conditions (temperature: 20 to $25^{\circ} \mathrm{C}$; salinity: $25 \%$ ) were provided by Dr J. McConaugha of Old Dominion University. These were used along with our group to develop a predictive relationship between LF and age.

For field comparisons 500 crabs were collected from Chesapeake Bay and Chincoteague Bay, Maryland, USA, in the fall of 1997 using commercial watermen. These wild populations were used to establish a baseline with which to compare laboratory results. The Chincoteague Bay differs from the Chesapeake in that the system maintains an annual mean salinity of $30 \%$ (Cargo 1958) compared to a significantly lower level in the Chesapeake (<25\%; Lippson 1973). Temperature for each sampling site are relevant (difference of mean annual temperature: $<2^{\circ} \mathrm{C}$ ). Comparison of these 2 populations allowed a preliminary examination of the effect of salinity on LF content.

Sample preparation. Crabs collected from the field or maintained in the laboratory were anesthetized on ice prior to being sacrificed. After morphological measurements were taken, brain and eye-stalk tissues were carefully excised (Fig. 1a). Retinal tissues were separated from eye-stalks and discarded because they contain substantial levels of pigment (i.e. retinol) which can overlap with the fluorescence spectra of LF (Hill \& Womersley 1991). Each collected tissue was a

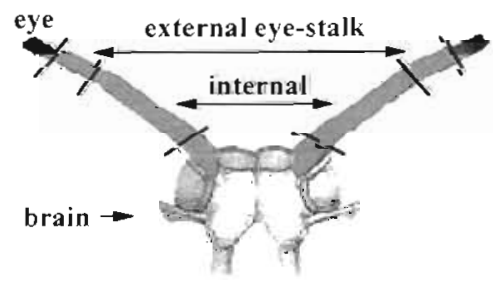

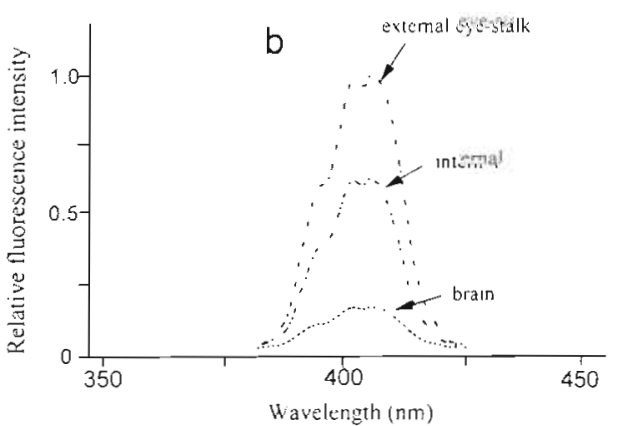

Wavelength (nm)
Fig. 1. (a) Illustration showing tissue sections from the blue crab Callinectus sapidus (modified from Bullock \& Horridge 1965) used for lipofuscin (LF) determination, (b) comparative fluorescence emission spectra of extractable LF at maximum excitation of $340 \mathrm{~nm}$ 
transferred to a $4 \mathrm{ml}$ amber vial for solvent extraction of LF. Sampled tissues for LF analysis and emission fluorescence spectra of extractable LF from tissues are shown in Fig. 1. LF extracted from external eye-stalk showed the highest fluorescence intensity and thus were used for quantifying LF in this study (Fig. 1b).

Analysis of extractable LF. Brains and eye-stalks were extracted and immediately analyzed to minimize potential problems of preservation and sample handling described by Nicol (1987) and Hill \& Womersley (1991). Extraction efficiency for samples (especially eye-stalks with calcareous exoskeleton) was optimal using a mixture of dichloromethane $\left(\mathrm{CH}_{2} \mathrm{Cl}_{2}\right)$-methanol $(\mathrm{MeOH})(2: 1, \mathrm{v} / \mathrm{v})$, which is comparable with previous studies. Tissues were extracted with $4 \mathrm{ml}$ mixture of $\mathrm{CH}_{2} \mathrm{Cl}_{2}-\mathrm{MeOH}$ with sonication using a microprobe (20 $\mathrm{W}$ for $2 \mathrm{~min}$ ). The samples were then centrifuged at $800 \times g$ for 10 min to remove cellular debris. A portion of the total extract was transferred to a $4 \mathrm{ml}$ vial and dried under $\mathrm{N}_{2}$. This was redissolved in methanol (1 $\mathrm{ml})$ and transferred to a $1 \mathrm{~cm}$ quartz cuvette. Smaller/limited samples were analyzed in a microcuvette $(200 \mu \mathrm{l})$. Analysis used a Hitachi 4500 scanning fluorescence spectrophotometer at room temperature (ca $20^{\circ} \mathrm{C}$ ). Fluorescence intensity was read at a maximum emission wavelength of 405 to $410 \mathrm{~nm}$ using a maximum excitation at $340 \mathrm{~nm}$

The quantification of extractable LF was calibrated using quinine sulfate dissolved in $0.1 \mathrm{~N} \mathrm{H}_{2} \mathrm{SO}_{4}$ which has a maximum emission wavelength at $450 \mathrm{~nm}$ with excitation at $340 \mathrm{~nm}$. To provide a quantitative measure of LF in tissue, fluorescence intensities as concentration were normalized to protein content of extracted tissues (Eq. 1) measured by the modified bicinchoninic acid (BCA) assay described by Nguyen \& Harvey (1994).

$$
\begin{aligned}
& \mathrm{LF} \text { index } \\
& \left(\mu \mathrm{g} \mathrm{mg} \mathrm{m}^{-1}\right. \text { protein) }
\end{aligned}=\frac{\begin{array}{c}
\text { Extractable LF concentration } \\
\text { calibrated vs quinine sulfate }\left(\mu \mathrm{ml}^{-1}\right)
\end{array}}{\begin{array}{c}
\text { Total protein content } \\
\text { (extract }+ \text { tissue })\left(\mathrm{mg} \mathrm{m}^{-1}\right)
\end{array}}
$$

Statistical analyses. LF measurements ( $\mu \mathrm{g} \mathrm{LF} \mathrm{mg}^{-1}$ protein) were log transformed before statistical analyses to satisfy assumptions for homogeneity of variances and normality of residuals. Correlation analyses were used to compare LF concentrations between the 2 different tissues (brain and eye-stalk) and between left and right eye-stalk from the same individual. For laboratory-reared crabs, analysis of variance (ANOVA) was first used to determine whether CW and eye-stalk LF content was affected by temperature and time, followed by monthly contrasts of CW and LF using protected Fisher's least significant difference (LSD) test. For field-collected samples, analysis of covariance (ANCOVA) was used to determine whether the relationship between CW (covariate) and eye-stalk LF con- tent was affected by gender or sampling sites. All statistical analyses were performed using SAS (version 6.12).

Modal analysis. Distribution of length $\mathrm{CW}$ frequency and extractable LF index for field-collected Chesapeake Bay and Chincoteague Bay male blue crabs were analyzed for modal separation. We specified that modal means should be separated by more than 2 standard deviations (SD) (Gulland \& Rosenberg 1992). LF index frequencies showed more than 2 modes and distributions were analyzed using ENORMSEP (Gayanilo et al. 1996), which is a maximum likelihood method for identifying modes. CW frequencies showed only a single mode and were not further analyzed. A Chisquared test was used to test the procedural assumption that frequencies were normally distributed for each mode. Class interval was specified at $0.02 \mathrm{LF}$ index because this exceeded the precision of the LF measurement and gave class size ranges between 5 and 25, typically most useful in analyzing distribution modes. Additionally, we assumed that the first mode in the LF-based frequency histogram is $1+(1$ to 2 yr old) age class since these crabs were collected in fall (November) and spawning occurs April-June (Johnson 1995)

\section{RESULTS}

\section{Methodological refinements}

The fluorescence of extractable LF in brain and eyestalk of blue crabs was found at a maximum emission wavelength of 405 to $410 \mathrm{~nm}$ with a maximum excitation at 340 to $350 \mathrm{~nm}$. These wavelength ranges match well with those reported in the literature for LF (see review by Hammer \& Braum 1988), particularly the data reported for the spider crab Hyas araneus (Hirche \& Anger 1987), and for the nematode Caenorhabditis elegans (Davis et al. 1982). A second emission maximum at 510 to $520 \mathrm{~nm}$ (at excitation wavelength of 340 to $350 \mathrm{~nm}$ ) was found with extracted LF in eye-stalks. This second emission maximum appears due to the concomitant extraction of flavins known to be present in eye tissue (Fletch et al. 1973, Davis et al. 1982).

The relationship between LF contents of the 2 different tissues, brain and eye-stalk, were significantly correlated ( $\mathrm{r}=0.74 ; \mathrm{p}<0.01 ; \mathrm{n}=12$ ) although the overall fit was not strong (data not shown). Extractable LF content between left and right eye-stalks of individual crabs were significantly correlated $(r=0.86 ; p<0.005$; $\mathrm{n}=10$ ). For field-collected crabs, no difference in LF content in eye-stalks was apparent between males ( $\mathrm{n}=$ $385)$ and females $(n=151)(p>0.05)$ (Fig. 2). 


\section{Lipofuscin versus carapace width}

Protein-based LF concentration in eye-stalk varied positively with crab $\mathrm{CW}$, with juveniles having much lower concentrations compared to adults (Fig. 2). CW for adult males and females from Chincoteague Bay were significantly smaller (t-test; $p=0.001$ ) compared to those from the Chesapeake system, as has been historically observed (Cargo 1958). Adult (CW $\geq 120 \mathrm{~mm}$ ) males collected from Chesapeake Bay had mean CW of $148.6 \pm 13.5 \mathrm{~mm}$ $($ mean $\pm \mathrm{SD})(\mathrm{n}=180)$ and females, $148.6 \mathrm{~cm} \pm$ $10.7 \mathrm{~mm}(n=60)$. Adult crabs collected from Chincoteague Bay had mean $\mathrm{CW}$ of $137.3 \pm$ $13.9 \mathrm{~mm}(\mathrm{n}=180)$ and $139.8 \pm 0.7 \mathrm{~mm}(\mathrm{n}=60)$ for males and females, respectively. LF concentrations in eye-stalks of crabs between 2 systems, however, were not significantly different (ANCOVA; $p>0.05$ ). The relationship between CW and LF index of all field-collected crabs was significant $(p<0.001)$ albeit weakly correlated $(\mathrm{r}=0.18)$.

Table 1 Results of 2-way ANOVA examining effects of temperature and time (month class) on size (CW: carapace width including lateral spines) and LF index ( $\log _{e}$ transformed) of laboratory-reared crabs ( $\mathrm{n}=3$ to 10 ). F: variance ratio; $\mathrm{p}$ : probability of type If error; df: degree of freedom; NS: not significant $(p>0.05)$

\begin{tabular}{|lccc|}
\hline Effect & df & $F$ & $p$ \\
\hline Size $(\mathrm{CW})$ & & & \\
Temperature & 1 & 12.17 & 0.0011 \\
Time & 5 & 21.55 & 0.0001 \\
Temp. $\times$ Time & 3 & 2.22 & NS \\
LF index & & & \\
Temperature & 1 & 0.99 & NS \\
Time & 5 & 4.81 & 0.0014 \\
Temp. $\times$ Time & 3 & 0.55 & NS \\
\hline
\end{tabular}

Table 2. Monthly mean CW and LF index with the results of Fisher's LSD test. Values followed by the same letter(s) are not statistically different as determined by protected Fisher's LSD test at $\mathrm{p}=0.05$

\begin{tabular}{|cccc|}
\hline $\begin{array}{c}\text { Time } \\
(\mathrm{mo})\end{array}$ & $\begin{array}{c}\text { Mean CW }(\mathrm{mm}) \\
\text { in ambient } \\
\left(20-28^{\circ} \mathrm{C}\right) \\
\text { water }\end{array}$ & $\begin{array}{c}\text { Mean CW }(\mathrm{mm}) \\
\text { in constant } \\
\text { temperature } \\
\left(20^{\circ} \mathrm{C}\right) \text { water }\end{array}$ & $\begin{array}{c}\text { Mean of the } \\
\text { LF index }\end{array}$ \\
\hline 0 & $51.1^{\mathrm{a}}$ & $51.1^{\mathrm{a}}$ & $0.079^{\mathrm{a}}$ \\
1 & $77.1^{\mathrm{b}}$ & $59.9^{\mathrm{bb}}$ & $0.082^{\mathrm{ab}}$ \\
2 & $89.1^{\mathrm{bc}}$ & $69.4^{\mathrm{bc}}$ & $0.110^{\mathrm{bc}}$ \\
3 & $103.9^{\mathrm{c}}$ & $80.9^{\mathrm{cd}}$ & $0.127^{\mathrm{c}}$ \\
5 & - & $94.6^{\mathrm{d}}$ & $0.161^{\mathrm{c}}$ \\
6 & - & $87.1^{\mathrm{cd}}$ & $0.171^{\mathrm{d}}$ \\
\hline
\end{tabular}

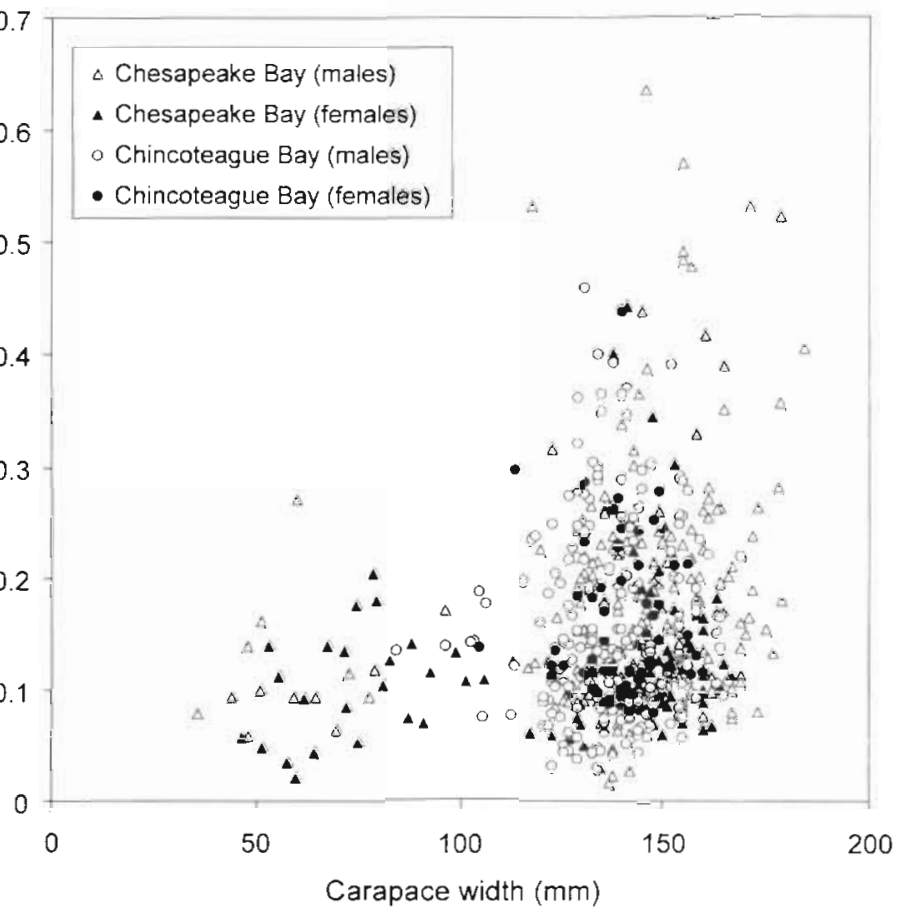

Fig. 2. Plot of carapace width (CW) versus LF index of 536 crabs ( 385 males and 151 females) collected from Chesapeake and Chincoteague Bays. Juveniles (<120 mm) were collected in summer 1997 from Calvert Cliffs, Maryland, USA

\section{Ageing resolution using extractable lipofuscin}

Growth rates of juveniles reared at ambient (higher) temperatures grew significantly faster than crabs reared at a constant $20^{\circ} \mathrm{C}$, based on CW (ANOVA; $p=0.001)$. LF accumulation in eye-stalks, however, showed no significant differences $(p>0.05)$, between temperature levels (Table 1). Because there was no affect of temperature on the protein-based LF index, samples were pooled and tracked as a single group. Monthly contrasts of LF indicated that time periods separated by less than 3 mo did not significantly differ (Table 2). Monthly contrasts of $\mathrm{CW}$ showed similar temporal differences at $20^{\circ} \mathrm{C}$, but greater month differences in CW under ambient condition where the average temperature was higher.

We estimated the time dependent LF accumulation of blue crabs using LF content in eye-stalk using known-age crabs together with field-collected juveniles (assumed to be $1.25 \mathrm{yr}$ old at start of rearing period) reared in the laboratory for 6 mo. A exponential function was constructed to describe the relationship between known or assumed ages of reared crabs and their LF index in eye-stalk. The equation (LF index [eye-stalk] $=0.019 \mathrm{e}^{1142 \text { age (as year) }}, \mathrm{p}=0.0001$ ) was significant and could explain $49 \%$ of the variation of the LF index (Fig. 3). 
Fig. 3. LF accumulation rate of known age crabs raised from megalope ( $\mathbf{\Lambda}$ ) or juveniles collected from the field and subsequently reared in the laboratory for 6 mo (⿴). Fieldcollected juveniles were assumed to have spawned during May 1996. The regression and $r^{2}$ for the exponential regression include all values ( $\mathrm{n}=3$ to 10 )

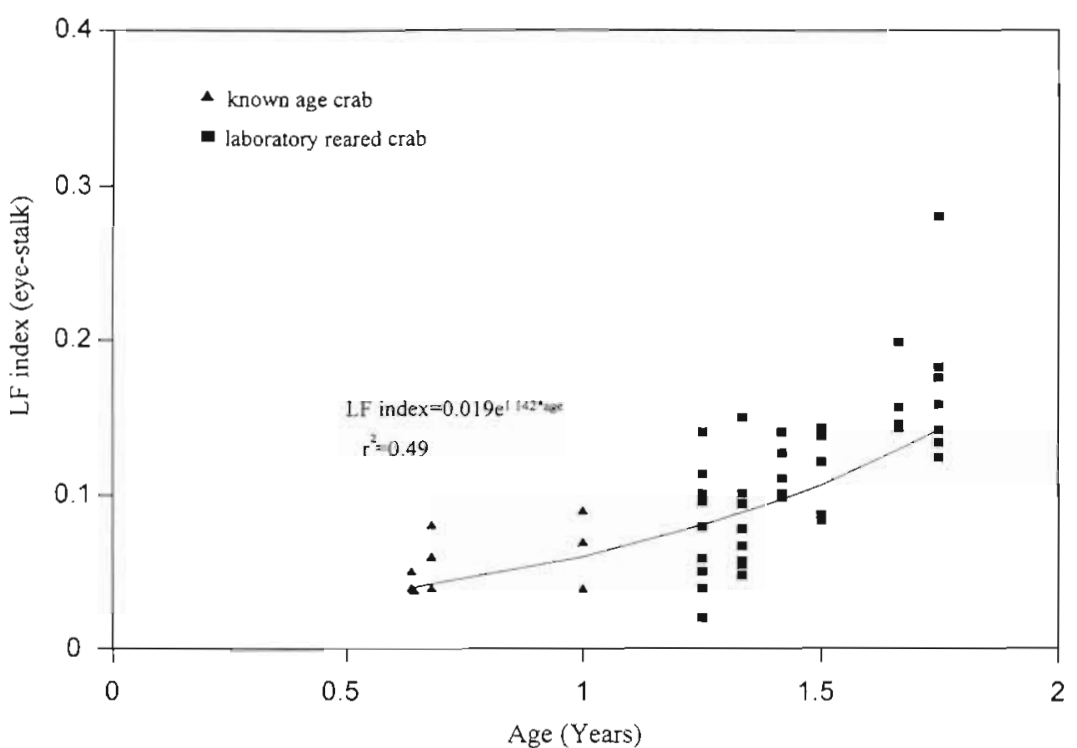

Fitted LF index means (by FISAT) of $1+$ age class were very close (deviating less than $5 \%$ ) to the LF index value $(0.11$ at age $=1.5 \mathrm{yr}$ ), obtained from the exponential regression of laboratory rearings (Table 2). Frequency distributions for the LF index showed multiple modes for both field samples (Fig. 4b,d). Fitted distributions to modal means supported the separation of modes since mean intervals were all greater than $2 \mathrm{SD}$ for the first 3 modes in each sample (Table 2). For both populations, LF index-based modal greater or equal to 2 yr in age (Rugulo et al. 1998).

\section{Chesapeake Bay}

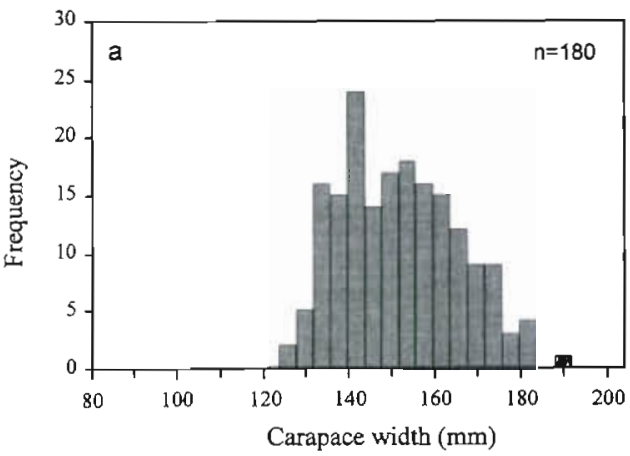

Fig. 4. Frequency histograms based on $\mathrm{CW}(\mathrm{a}, \mathrm{c})$ and LF index $(b, d)$ in eyestalk for adult male crabs collected from Chesapeake $(\mathrm{n}=180)$ and Chincoteague Bays $(\mathrm{n}=180)$. Solid lines (b, d) are derived from a predicted frequency distribution and dashed lines show normally distributed components of each mode based on the ENORMSEP analysis, $1+$ age mode consists of individuals 1 to 2 yr old

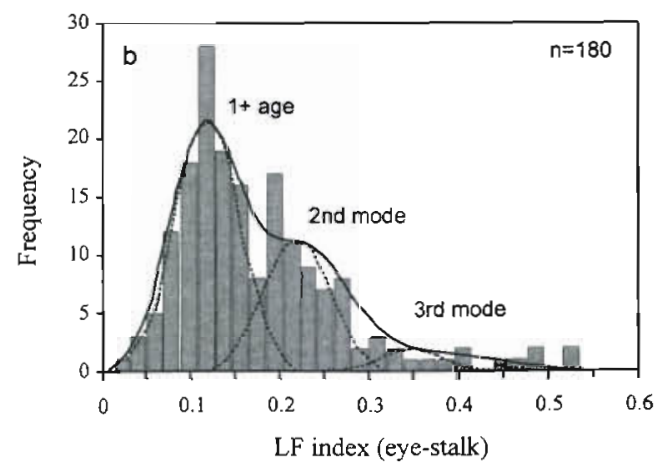

Chincoteague Bay
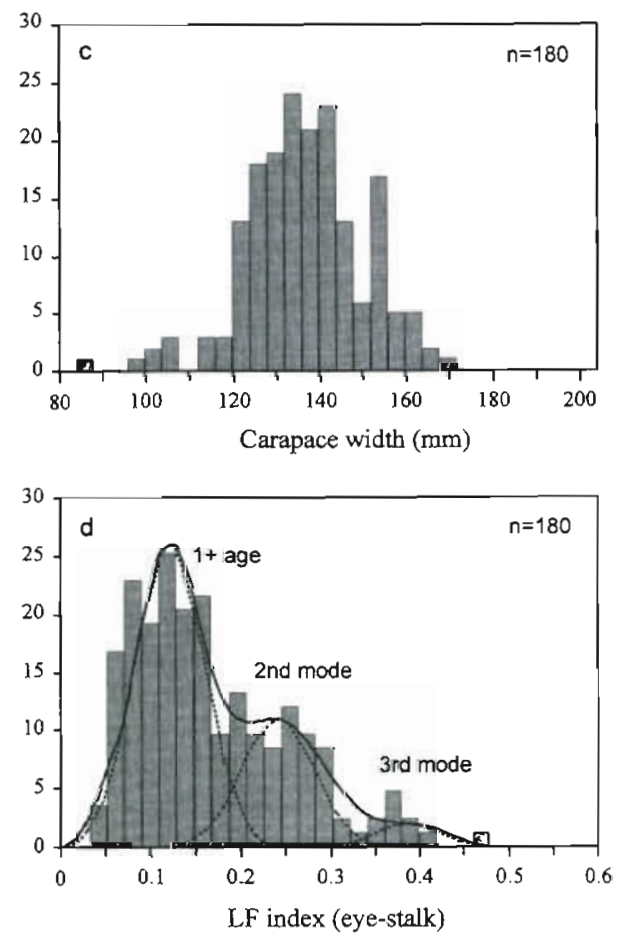
Table 3. Modal frequency analysis of LF index for Chesapeake and Chincoteague Bay samples. $\chi^{2}$ : chi-square test; $\mathrm{df}_{\text {: }}$ degree of freedom; $1+$ age: this mode consists of individuals 1 to 2 yr old

\begin{tabular}{|lcccc|}
\hline Mode & $\begin{array}{c}\text { Chesapeake Bay } \\
\text { Mean LF No. of ind. } \\
\pm \text { SD } \\
\text { mode }^{-1}\end{array}$ & \multicolumn{2}{c|}{$\begin{array}{c}\text { Chincoteague Bay } \\
\text { Mean LF }\end{array}$} & $\begin{array}{c}\text { No. of ind. } \\
\text { mode }^{-1}\end{array}$ \\
\hline 1+ age & $0.106 \pm 0.035$ & 96 & $0.110 \pm 0.017$ & 104 \\
2nd mode & $0.216 \pm 0.045$ & 69 & $0.232 \pm 0.037$ & 67 \\
3rd mode & $0.346 \pm 0.066$ & 15 & $0.380 \pm 0.021$ & 9 \\
$\chi^{2}$ & 10.85 & & 17.83 & \\
df & 24 & & 22 & \\
\hline
\end{tabular}

distributions were not significantly different from predicted normal distributed frequencies (Chi-square test; at $95 \%$ level of confidence). Unfortunately, it is difficult to assign the age value beyond $1.8 \mathrm{yr}$ through modal analysis due to the lack of a calibrated LF index data for $>2$ yr old crabs. For Chesapeake Bay crabs, several LF values were beyond the third mode which suggested crabs of greater longevity. However, this mode could not be statistically distinguished from the third mode. In both Chesapeake Bay and Chincoteague Bay samples, modal frequencies declined more than $30 \%$ between the first and second modes and more than 3 -fold between the second and third modes (Table 3).

\section{DISCUSSION}

The blue crab plays an important ecological and economic role in many temperate estuaries yet age information has been lacking. Results for field collections and short-term rearing experiments suggest that protein-based LF measures may provide a method for significant improvement for estimation of age structure in Callinectes sapidus. While modal analysis based on CW only discerned a single mode, protein-normalized LF concentrations in eye-stalks showed multiple modes. Multiple modes would be expected based on current knowledge of spawning behavior and longevity. The results also showed a successive decrease in modal amplitude with succeeding modes. Given the life history and recruitment dynamics of the blue crab in estuarine systems (van Engel 1958), this pattern of decreasing amplitude with increasing age seems a reasonable scenario, particularly in the Chesapeake Bay where harvesting pressure is high (Rugulo et al. 1998). These results are quite similar to a recent LF modal analysis conducted on lobster (western rock lobster Panulirus cygnus) by Sheehy et al. (1998) where better age-class separation was obtained using LF rather than size.
The successful use of eye-stalk ganglia rather than brain tissue for LF quantification has been demonstrated previously for the European lobster Homarus gammarus using fluorescence microscopy (Sheehy et al. 1996). The advantages of using neural tissue in eye-stalks compared to dissection of brain tissue are many. Foremost is the ability for rapid sampling of tissue to minimize artifacts associated with extended sample handling (e.g. Hill \& Womersley 1991). Eyestalks can be excised and the chitinous sheath removed in minutes prior to extraction to minimize the possibility of sample alteration prior to analysis (Nicol 1987). At least in principle, the use of eyestalks also provides the potential for collection of a second measure from a single individual which would provide accurate LF accumulation rate information This has yet to be confirmed, however, and the localization of the primary molting hormone for Callinectes sapidus in the eye-stalk (Skinner 1985) could have physiological repercussions which may compromise any values obtained. Additional studies are currently underway to examine the potential for sequential sampling of eye-stalks in tagged crabs. From an economic perspective, removal of the eye-stalk does not compromise the crabs' market condition, an important aspect for commercial species and one also noted by Sheehy et al. (1996) for lobster.

Despite the fact that LF accumulates in tissues with age, a quantitative relationship between the amount of extractable LF (measured by spectrofluorometry) and the volume fraction as intact granules (determined by fluorescence microscopy) has not yet been established.

Many of the concerns have been presented elsewhere (e.g. Hill \& Womersley 1991), and include both analytical procedures and fundamental properties of the pigments themselves. One important variable has been the appropriate basis on which to quantify fluorescent intensity from tissues. Although fluorescence intensity itself can be accurately calibrated against external standards, LF per unit tissue volume has often relied on wet or dry weight of small tissue samples, either before or after extraction (e.g. Ettershank \& George 1984). Such measures are inherently variable and subject to differences among tissue types and processing methods. Our use of cellular protein as a basis for measurement of extractable LF concentrations eliminates many of the difficulties encountered previously in its application. Rather than wet weight or other mass measures, protein provides a more representative value of cellular material extracted, and current methods allow for high sensitivity and wide dynamic range. Careful attention to sample extraction, handling and analysis (see Hill \& Womersley 1991) together with accurate values for tissue protein allow 
extractable measurement of LF to provide a sensitive measure of its accumulation in crustacean neural tissues.

A second concern has been the discrepancy between fluorescence maxima of age pigments seen in extracts compared to intact granules viewed within tissue sections. Many workers (e.g. Sheehy 1996) have observed that intact LF present in granules have maxima at significantly longer wavelengths ( 500 to $600 \mathrm{~nm}$ ) than that seen for LF in extracts of the same tissue measured spectrofluorometrically (typically 400 to $500 \mathrm{~nm}$ ). For the blue crab, fluorescence maxima were similar to other studies of extracted FAP, with little observed fluorescence above $500 \mathrm{~nm}$ which could not be attributed to other cellular constituents (i.e. flavin). One explanation for the variation in fluorescent signature appears not to be inherent structural differences in extractable and native LF per se, but rather that the observed fluorescence maxima is concentration dependent. Yin \& Brunk (1991) examined a variety of potential age pigment fluororphores, including Shiff-bases and aldehydes, and found that the emission maximum shifted to longer wavelengths as concentration increased. Shifts were significant (up to $126 \mathrm{~nm}$ ), and dependent upon the dilution used and other compounds in the matrix. This concentration dependent fluorescence shift might in part reconcile the common observation of blue fluorescence observed for age pigment in solution compared to the yellow fluorescence seen in intact granules where such pigments are highly concentrated (Yin 1996).

For field-collected crabs, the weak relationship between CW and eye-stalk LF index was due to the high variability of the size in the same age crabs or the variability of the possible age structure in the population. We had also expected that LF at a given size might be higher for females than males. Evidence indicates that shortly after their initial copulation, blue crab females molt for a single last time, at a relatively small size (CW < 130mm; Millikin \& Williams 1984). Females living beyond this molt should accumulate LF independently of size. However, we did not observe that females had higher LF content than males at the same size. This may be explained by low survival beyond first spawning or a change in LF accumulation rate after the terminal molt.

The laboratory rearing experiment showed that the resolution of LF ageing was less than 6 mo (Table 2) and LF reliably predicted chronological age in laboratory-reared crabs held until they were approximately $1.8 \mathrm{yr}$ old. While results were encouraging, such highly precise measures should be cautiously evaluated and may not be applied directly to crabs in nature. Other environmental variables such as food supply which alter metabolic rate, but which were held constant in our experiments, might influence accumulation rates of LF.

Among environmental factors, temperature would be expected to be an important contributor to rates of LF accumulation due to its influence on metabolic rate. In our short-term laboratory rearing experiment, however, temperature $\left(20^{\circ} \mathrm{C}\right.$ vs 20 to $\left.28^{\circ} \mathrm{C}\right)$ failed to significantly influence LF accumulation (Table 1). This suggests that either the temperature difference (less than $8^{\circ} \mathrm{C}$ ) in the 3 mo experiment was insufficient to influence the LF accumulation or that the more rapid growth rate for crabs held at ambient temperatures (higher than $20^{\circ} \mathrm{C}$ ) resulted in simultaneous increases in protein content and LF which would be interpreted as no apparent increase in the LF index. Indeed, other studies have noted lowered LF accumulation during periods of rapid growth akin to growth dilution (Siakotos et al. 1977, Hill \& Womersley 1991). We believe that the exponential rate of increase of LF index with age (Fig. 3) indicates that LF was being retained as a cumulative product through the life span of the crab. Although this relationship has not been consistently observed between systems (Hill \& Womersley 1993), these results further emphasize the need to calibrate LF-based age with temperature, particularly the potential effect of seasonal variations.

A potential concern from LF modal analysis is the assignment of $1+$ age individuals at a given size. Modal analysis of field collections assumed $1+$ age at $\mathrm{CW}$ $\geq 120 \mathrm{~mm}$, even though laboratory-reared crabs at this age were smaller ( $\mathrm{CW}<120 \mathrm{~mm}$; Table 2 ). Typical age designations for stock assessment purposes assume $1+$ age individuals to be CW 60 to $120 \mathrm{~mm}$, which appears a very conservative value based on smaller size in laboratory rearings. We have recently observed in enclosed ponds under semi-natural conditions that $\leq 1$ yr old juveniles (mean $\mathrm{CW}=50 \mathrm{~mm}$ ) grow rapidly and reach adult size (mean $\mathrm{CW}=150 \mathrm{~mm}$ ) within $3 \mathrm{mo}$ (by August to November). It appears that laboratory reared crabs grew at lower rates than would be expected in nature. As a result, we believe it is appropriate to assign many field-collected adults $(\mathrm{CW}>$ $120 \mathrm{~mm}$ ) an $1+$ age

Although the results obtained from field collections are encouraging, it remains to be determined whether the accumulation of extractable LF is growth, size, or age dependent, because the precise age of field-collected experimental crabs is unknown. Results from rearing experiments supported the use of LF index to understand population dynamics. Yet because we have thus far only examined a limited segment of the blue crab potential life span (less than 2 yr), additional studies are needed which include a more comprehensive age range for crabs reared under semi-natural conditions 


\section{CONCLUSIONS}

Differences in extractable LF concentration (as a protein-indexed measurement) exist among blue crabs of different sizes, indicating approximate ages of crabs collected from the field. Among the field-collected and laboratory-reared crabs, gender differences did not significantly affect LF accumulation. Among the small sample size used in rearing studies, LF accumulation can be distinguished among crabs which differ in age by less than 6 mo. LF-based frequency histograms derived from field collections support the hypothesis that extractable LF allows estimates of age for the blue crab. The results of this preliminary study support the use of extractable LF for age determination of blue crabs.

Acknowledgements. We thank John McConaugha for samples of known age crabs and Troy Gunderson for technical assistance. Anne Richards provided helpful comments on an early version of the manuscript and Steve Cadrin and 3 anonymous reviewers substantially improved the final version. We also thank Brenda Yates for manuscript preparation. This work was supported by NOAA grant NA76FU0560 through the Chesapeake Bay Program. The views expressed are those of the authors and do not necessarily reflect the views of NOAA or any of its subagencies. Contribution number $32 / 6$ of the University of Maryland Center for Environmental Science.

\section{LITERATURE CITED}

Belchier MP, Shelton M, Chapman CJ (1994) The identification and measurement of fluorescent age-pigment abundance in the brain of a crustacean (Nephrops norvegicus) by confocal microscopy. Comp Biochem Physiol 108B: $157-154$

Belchier M, Edsman L, Sheehy MRJ, Shelton PM (1998) Estimating age and growth in long-lived temperate freshwater crayfish using lipofuscin. Freshw Biol 39:439-446

Bullock TH, Horridge GA (1965) Structure and function in the nervous systems of invertebrates, Vol II. Freeman WH \& Co, San Francisco

Cargo DG (1958) The migration of adult female blue crabs, Calinectus sapidus Rathbun, in Chincoteague and adjacent waters. J Mar Res 16(3):180-191

Clarke A, Kendall MA, Gore DJ (1990) The accumulation of fluorescent age pigments in the trochid gastropod Monodonta lineata. J Exp Mar Biol Ecol 144:185-204

Davis BO, Anderson GL, Dusenberg DB (1982) Total luminescence spectroscopy of fluorescent changes during aging in Caenorhabditis elegans. Biochemistry 21:4089-4095

Ettershank G, George RY (1984) A new approach to the assessment of longevity in the Antarctic krill Euphausis superba. J Crust Biol 4:295-305

Fletch BL, Dillard CJ, Tappel AL (1973) Measurement of fluorescent lipid peroxidation products in biological systems and tissues. Anal Biochem 52:1-9

Gayanilo FC Jr, Sparre P, Pauly P (1996) FAO/ICLARM stock assessment tools (FISAT). FAO, Rome

Gulland JA, Rosenberg AA (1992) A review of length-based approaches to assessing fish stocks. FAO Fisheries Technical Paper 323, Rome, Italy
Gutteridge JMC (1987) Oxygen radicals, transition metals and aging. In: Totaro EA, Glees P, Pisanti FA (eds) Advances in the biosciences 64. Pergamon Press, Oxford, p $1-22$

Hammer C, Braum E (1988) Quantification of age pigments (lipofuscin). Comp Biochem Physiol 90B(1):9-17

Hannover A (1842) Mikroskopische undersolgeser af nervensystemet. K Danske Vidensk Selsk Skr (Nat Math Afh) 10: $1-112$

Hill KT, Womersley C (1991) Critical aspects of fluorescent age-pigment methodologies: modification for accurate age assessment in aquatic organisms. Mar Biol 109:1-11

Hill KT, Womersley C (1993) Interactive effects of some environmental and physiological variables on fluorescent age pigment accumulation in brain and heart tissues of an aquatic poikilotherm. Environ Biol Fish 37(4):397-405

Hirche HJ, Anger K (1987) The accumulation of age pigments during larval development of the spider crab. Hyas araneus (Decapoda, Majidae). Comp Biochem Physiol 88B(3): $777-782$

Hjort J, Lea E (1914) The age of a herring. Nature 94:255-256

Johnson DR (1995) Wind forced surface currents at the entrance to Chesapeake Bay: their effect on blue crab larval dispersion and post-larval recruitment. Bull Mar Sci $57(3): 726-738$

Katz ML, Robison WG Jr, Herrmann RK, Groome AB, Bieri JG (1984) Lipofuscin accumulation resulting from senescence and vitamin E deficiency: spectral properties and tissue distribution. Mech Ageing Dev 25:149-159

Lippson RL (1973) Blue crab. In: Lippson AJ (ed) The Chesapeake Bay in Maryland. An atlas of natural resources. Johns Hopkins Univ Press, Baltimore, MD

Millikin MR, Williams AB (1984) Synopsis of biological data on the blue crab, Callinectes sapidus Rathbun. NOAA Technical Report NMFS1, US Dep Commer, NOAA, Natl Mar Fish Serv, Washington, DC

Nguyen RT, Harvey HR (1994) A rapid micro-scale method for the extraction and analysis of protein in marine samples. Mar Chem 45:1-14

Nicol S (1987) Some limitations on the use of the lipofuscin ageing technique. Mar Biol 93(4):609-614

Nicol S, Stolp M, Hosie GW (1991) Accumulation of fluorescent age pigments in a laboratory population of Antarctic krill Euphausis superba Dana. J Exp Mar Biol Ecol 146 : $153-161$

O'Donovan V, Tully O (1996) Lipofuscin (age pigment) as an index of crustacean age: correlation with age, temperature and body size in cultured juvenile Homanus gammarus L. J Exp Mar Biol Ecol 207:1-14

Prager $\mathrm{MH}_{1}$ McConaugha JR, Jones CM, Greer PJ (1990) Fecundity of blue crab, Callinectes sapidus, in Chesapeake Bay. Biological, statistical, and management considerations. Bull Mar Sci 46:170-179

Rothschild B, Ault J, Patrick E, Smith S, Li H, Maurer T Daugherty B, Davis G, Zhang C, McGarvey R (1992) Assessment of the Chesapeake Bay blue crab stock. Univ of Maryland, Chesapeake Bay Biological Lab, CB92-003036, CEES 07-4-30307, Solomons, MD

Rugulo L, Knotts KS, Lange AM, Crecco VA (1998) Stock assessment of Chesapeake Bay blue crab (Callinectes sapidus Rathbun). J Shellfish Res 17(2):493-517

Secor DH, Dean JM, Campana SE (1995) Recent developments in fish otolith research. Belle W (ed) Baruch Library in Marine Sciences Number 19. University of South Carolina Press, Columbia, SC

Sheehy MR (1992) Lipofuscin age-pigment accumulation in the brain of ageing field-and laboratory-reared crayfish 
Cherax quadricarinatus (von Martens) (Decapoda: Parastacidae). J Exp Mar Biol Ecol 161:79-89

Sheehy MR (1996) Quantitative comparison of in situ lipofuscin concentration with soluble autofluorescence intensity in the crustacean brain. Exp Geron 31(3):421-432

Sheehy MR, Cameron E, Marsden G, McGrath J (1995) Age structure of female giant tiger prawns Penaeus monodon as indicated by neuronal lipofuscin concentration. Mar Ecol Prog Ser 117:59-63

Sheehy MR, Shelton PMJ, Wickins JF, Belchier M, Gaten E (1996) Ageing the European lobster Homarus gammarus by lipofuscin in its eyestalk ganglia. Mar Ecol Prog Ser 143:99-111

Sheehy MR, Caputi N, Christopher C, Belchier M (1998) Use of lipofuscin for resolving cohorts of western rock lobster (Parulirus cygnus). Can J Fish Aquat Sci 55:925-936

Siakotos AN, Armstrong D, Koppay N, Muller J (1977) Biochemical significance of age pigment in neurons. In:

Editorial responsibility: Kenneth Tenore /Contributing Editor), Solomons, Maryland, USA.
Nandy K, Shervin I (eds) The aging brain and senile dementia. Plenum Press, New York, p 99-118

Skinner DM (1985) Molting and regeneration. In: Bliss DE, Mantel LH (eds) The biology of the crustacea, Vol 9. Academic Press, New York, p 43-146

Van Engel WA (1958) The blue crab and its fishery in Chesapeake Bay. Part I. Reproduction, early development, growth, and migration. Commer Fish Rev 20(6):6-17

Wahle RA, Tully O, O'Donovan V (1996) Lipofuscin as an indicator of age in crustaceans: analysis of the pigment in the American lobster Homarus americanus. Mar Ecol Prog Ser 138:117-123

Yin D (1996) Review article: biochemical basis of lipofuscin ceroid, and age pigment-like fluorophores. Free Radical Biol Med 21(6):871-888

Yin DZ, Brunk UT (1991) Microfluorometric and fluorometric lipofuscin spectral discrepancies: a concentration-dependent metachromatic effect? Mech Ageing Dev 59:95-109

Submitted: November 20, 1998; Accepted: April 19, 1999 Proofs received from author(s): July 30, 1999 